\title{
Loss of genetic diversity and increased genetic structuring in response to forest area reduction in a ground dwelling insect: a case study of the flightless carabid beetle Carabus problematicus (Coleoptera, Carabidae)
}

\author{
EVA GAUBLOMME, ${ }^{1,2}$ KEVIN MAEBE, ${ }^{1}$ KARINE VAN DONINCK, ${ }^{3}$ \\ HILDE DHUYVETTER, ${ }^{1}$ XIANG LI, ${ }^{3}$ KONJEV DESENDER $^{1 \dagger}$ and \\ FREDERIK HENDRICK X ${ }^{1,2}{ }^{1}$ Department of Entomology, Royal Belgian Institute of Natural \\ Sciences, Brussels, Belgium, ${ }^{2}$ Biology Department, Terrestrial Ecology Unit, Ghent University, Ghent, Belgium and \\ ${ }^{3}$ University of Namur, Namur, Belgium
}

\begin{abstract}
Old growth temperate broadleaved forests are characterised by a large proportion of forest specialists with low dispersal capability. Hence, species bound to this habitat are expected to be highly susceptible to the effects of decreasing patch size and increasing isolation.

2. Here, we investigate the relative effect of both factors by genotyping individuals of a flightless and forest specialist beetle Carabus problematicus from 29 populations, sampled in 21 different forest fragments in Belgium, at eight microsatellite loci.

3. A high degree of genetic differentiation among fragments was observed, with populations from smaller forests being considerably more differentiated and characterised by a lower genetic diversity compared to those of larger forests.

4. A more detailed study on forest remnants of a former historic continuous woodland area revealed that population differentiation was high among, but not within remnants, irrespective of geographical distance. This suggests that patch fragmentation rather than geographical distance is the ultimate factor that hampers gene flow in this species.

5. The results indicate that gene flow among suitable habitat patches is primarily reduced by the inability of this specialised species to traverse the landscape matrix. This lack of dispersal may pose a serious threat for the persistence of $C$. problematicus and ecologically similar species, and suggests that present populations can best be protected by securing or increasing the size of existing habitat patches.
\end{abstract}

Key words. Genetic differentiation, ground beetle, habitat fragmentation, isolation, microsatellites, population genetics.

\footnotetext{
Correspondence: Eva Gaublomme, Department of Entomology, Royal Belgian Institute of Natural Sciences, Vautierstr. 29, B-1000 Brussels, Belgium. E-mail: egaublomme@yahoo.com

$\uparrow$ †uthor deceased.
}

\section{Introduction}

The fragmentation and destruction of natural habitats is a key threat to biodiversity and a major issue of conservation biology (Harris, 1984; Meffe \& Caroll, 1997; Streiff et al., 2005). Fragmentation, deterioration and loss of 
habitat also threaten the survival of many insect species (Heisswolf et al., 2009), but effects will differ depending on the trophic level, dispersal ability and habitat specialisation (Ewers \& Didham, 2006) of the species under study. In particular, species with limited dispersal ability are expected to be the most vulnerable. Metapopulation theory predicts that habitat size and isolation are the most critical factors determining the occurrence and survival of populations in a fragmented landscape (Leisnham \& Jamieson, 2002). If a formerly continuous population is divided into several isolated fragments, this reduces the effective size of the populations within each fragment (Frankham et al., 2002; Keller et al., 2005), which increases the effect of stochastic local extinctions. When dispersal is limited, recolonisation of empty patches is strongly hampered and may ultimately result in the extinction of an entire metapopulation (Hanski, 1998; Roland et al., 2000; Frankham et al., 2002).

A well documented example of a landscape that suffered severe fragmentation are forest ecosystems in temperate Europe, which have been subjected to human influence for more than 7000 years (Bloemers \& Van Dorp, 1991; Verhulst, 1995; Honnay et al., 2005). In Belgium, the transition of natural forests to agricultural land has decreased forest cover by more than 70\% (Bloemers \& Van Dorp, 1991; Tack et al., 1993; Tack \& Hermy, 1998). Many forest organisms have been highly affected by this reduction in forest area, and it most probably led to the extinction of several species at a national level (Tack et al., 1993; Ervynck et al., 1994; Desender et al., 1999). Although habitat fragmentation is known to affect the long-term survival of many species, most studies in Belgium are conducted on plants (Bossuyt et al., 1999; Hermy et al., 1999; Honnay et al., 1999). However, studies that investigated the population genetic effects of landscape fragmentation on animals have shown that landscape deterioration may strongly affect genetic structuring (Keyghobadi, 2007). In particular, species incapable of flight and specialised species that are unlikely to find sufficient suitable habitat patches for dispersal (Brouat et al., 2004), are expected to be most vulnerable to the effects of increased patch isolation and decreasing habitat quality. Furthermore, the reduction in local effective population size may strongly increase genetic structure and result in an overall decrease in genetic variation (Frankham, 1996). This loss of genetic variation may ultimately reduce the survival and fitness of affected populations (Frankham, 1995; Ebert et al., 2002; Reed \& Frankham, 2003) and as such pose a threat to the long-term viability of populations (Frankham, 1996; Saccheri et al., 1996, 1998; Westemeier et al., 1998; Desender et al., 1999).

Given that genetic differentiation among populations is supposed to be high in species with narrow ecological niches, low dispersal capability and a lack of behavioural response to habitat fragmentation (Wiens et al., 1997), species that share these characteristics are ideal to study the population genetic consequences of habitat fragmentation and to develop guidelines for the restoration of habitat remnants. Such restoration measures may include the creation of new habitat patches, the enlargement of existing ones or increasing the connectivity of existing patches in order to mitigate the effects of fragmentation. Especially within densely populated and urbanised areas, there is a strong need for such guidelines among policy makers, managers and conservation practitioners.

The forest carabid beetle Carabus problematicus occurs from Finland to Southern France, including the British Isles (Turin, 2000), with Belgium situated in the centre of its distribution. Because this ground beetle species is incapable of flight, long-distance dispersal is not possible, and it is therefore expected to suffer from isolation and fragmentation. Here, we investigate the genetic structure of $C$. problematicus populations in a fragmented landscape and evaluate how this can be related to the factors forest area and geographical distance.

\section{Materials and methods}

\section{Study species}

Carabus problematicus Herbst, 1786 in our study region is a strictly nocturnal forest specialist beetle that is incapable of flight. Movement up to 70-75 m per night has been observed (Neumann, 1971; Rijnsdorp, 1980). Although it is capable of dispersal by walking, this species is not able to cross the forest surrounding matrix.

\section{Study area and sampling}

A total of 1221 beetles, distributed over 29 samples, were obtained from 21 different forest fragments scattered throughout Belgium, varying in size and degree of isolation (Table 1; Fig. 1). In some larger fragments that formerly belonged to the historic and continuous Kolenwoud forest (see below), multiple samples were taken (Table 1). About 40 beetles per sample were collected from May to September 2002 using live pitfall traps or by actively searching potential hibernation habitats during winter (e.g. bark of tree trunks). Traps were emptied every fortnight and up to 19 sampling campaigns were held depending on the difficulty to reach a sample of 40 individuals per sample.

Of particular interest was the Brussels Capital Region, with a range of four old growth forest fragments: Gasthuisbos, Rodebos, Meerdaalwoud and Soignes (Fig. 2). The historical ecology of these last forests is well documented (Van der Ben, 1992; Tack et al., 1993; Verhulst, 1995). All fragments originated from the historic forest Kolenwoud (Table 1; Fig. 1), which was a mediaeval forest, covering the central part of Belgium with a total area of 12000 ha. From the 12th century onwards, it was partly subdivided into smaller fragments and its total area reduced to 10382 ha in the 16th century (Van de Velde, 1992). In the 18th century, the largest part, constituting 
Table 1. Summary of the 29 Carabus problematicus samples, with forest fragment origin (forest fragment), size of the forest fragment in ha, sample size expressed as number of genotyped individuals $(N)$ and measures of genetic diversity at seven microsatellite loci in $29 C$. problematicus populations. Fragments indicated with $(\mathrm{K})$ were part of the former Kolenwoud, measures of genetic diversity were mean number of alleles per locus (A), average observed heterozygosity $\left(\mathrm{H}_{\mathrm{o}}\right)$, average expected heterozygosity $\left(\mathrm{H}_{\mathrm{e}}\right)$ and estimated allelic richness summed over all loci for a subset of 26 individuals (AR).

\begin{tabular}{|c|c|c|c|c|c|c|c|}
\hline Sample & Forest fragment & Fragment size (ha) & $N$ & A & $\mathrm{H}_{\mathrm{o}}$ & $\mathrm{H}_{\mathrm{e}}$ & $\mathrm{AR}$ \\
\hline Brak & Brakel & 243 & 44 & 4.43 & 0.49 & 0.51 & 28.86 \\
\hline Brasin & Inslag & 394 & 38 & 4.43 & 0.44 & 0.43 & 28.29 \\
\hline Bugg & Buggenhout & 176 & 61 & 3.71 & 0.35 & 0.37 & 22.66 \\
\hline Buze & Buzenol & 16200 & 41 & 4.86 & 0.50 & 0.59 & 33.27 \\
\hline Chanly & Chanly & 46199 & 40 & 5.71 & 0.59 & 0.67 & 38.28 \\
\hline Fernelm & Fernelmont & 168 & 29 & 3.29 & 0.44 & 0.50 & 22.92 \\
\hline Gasth & Gasthuisbos (K) & 39 & 33 & 3.71 & 0.49 & 0.48 & 25.50 \\
\hline Har & Harentbeek & 241 & 38 & 4.86 & 0.50 & 0.53 & 31.60 \\
\hline HVMuhl & Moelenbusch & 25000 & 39 & 5.14 & 0.53 & 0.54 & 32.93 \\
\hline HVRuhr & Ruhrbusch & 15310 & 39 & 5.00 & 0.53 & 0.57 & 33.09 \\
\hline Kalm & Withoefse Heide & 70 & 38 & 4.14 & 0.43 & 0.45 & 26.51 \\
\hline Kluis & Kluisbos & 274 & 39 & 4.29 & 0.40 & 0.47 & 28.46 \\
\hline Make & Bruinbos & 82 & 54 & 4.14 & 0.46 & 0.51 & 25.60 \\
\hline Meerddr & Meerdaalwoud (K) & 1575 & 36 & 5.71 & 0.57 & 0.58 & 37.58 \\
\hline MeerJ +60 & Meerdaalwoud (K) & 1575 & 40 & 6.29 & 0.54 & 0.56 & 39.24 \\
\hline MeerJ-40 & Meerdaalwoud (K) & 1575 & 40 & 5.71 & 0.57 & 0.58 & 36.49 \\
\hline MeerJ-60 & Meerdaalwoud (K) & 1575 & 40 & 6.14 & 0.55 & 0.57 & 39.39 \\
\hline Meerdkl & Meerdaalwoud (K) & 1575 & 35 & 5.57 & 0.56 & 0.57 & 36.55 \\
\hline MeerO +60 & Meerdaalwoud (K) & 1575 & 41 & 5.43 & 0.50 & 0.56 & 35.34 \\
\hline MeerO-115 & Meerdaalwoud (K) & 1575 & 37 & 5.86 & 0.48 & 0.52 & 37.32 \\
\hline Ppame & Amerloo-Asbroek & 152 & 39 & 4.43 & 0.37 & 0.47 & 29.29 \\
\hline Ppeer & Peerdsbos & 280 & 31 & 4.00 & 0.42 & 0.44 & 27.22 \\
\hline Rode & Rodebos (K) & 104 & 38 & 5.29 & 0.42 & 0.47 & 34.28 \\
\hline Roval & Rodebos (K) & 104 & 36 & 5.29 & 0.45 & 0.47 & 34.99 \\
\hline Soree & Soree & 30 & 48 & 4.57 & 0.49 & 0.52 & 29.41 \\
\hline Voer15 & Veursbos & 1031 & 37 & 4.14 & 0.47 & 0.47 & 28.00 \\
\hline Voer7 & Alserbos & 77 & 41 & 3.29 & 0.38 & 0.41 & 22.20 \\
\hline ZONP & Soignes (K) & 5103 & 37 & 5.57 & 0.53 & 0.58 & 36.89 \\
\hline ZONRK & Soignes (K) & 5103 & 36 & 5.14 & 0.57 & 0.58 & 34.28 \\
\hline Overall $( \pm \mathrm{SE})$ & & & & $4.83( \pm 0.17)$ & $0.515( \pm 0.01)$ & $0.482( \pm 0.01)$ & $31.92( \pm 5.44)$ \\
\hline
\end{tabular}

mostly of the current Soignes forest, had a total area of 10800 ha (Lefèbvre, 1997). From 1843 until now the remaining Soignes forest retained its current area of 4383 ha and forms together with other remnants (Table 1) the last remains of the former Kolenwoud. A thorough sampling on a smaller scale was conducted here, so that several samples per fragment were taken: Soignes $(n=2)$, Gasthuisbos $(n=1)$, Meerdaal $(n=7)$ and Rodebos $(n=2$; Table 1; Fig. 1). This detailed sampling in the Brussels Capital Region probably comprises most of the current Kolenwoud remnants in which the study species is still present (Gaublomme et al., 2008).

\section{Microsatellite genotyping}

A total of eight microsatellite markers was used to genotype each individual. The loci P44, P40, P97, P98, P55, P99 have previously been isolated from C. problematicus (Gaublomme et al., 2003), the other two loci, CV105136CMPG and CV104481CMPG, were selected from C. violaceus, Linnaeus 1758 (Keller \& Largiadèr, 2002; Keller Population Genetics CMPG lab, Bern, Switzerland, unpublished data). DNA was isolated from front legs of study species using the DNeasy blood and tissue kit (Qiagen Benelux, Venlo, the Netherlands). PCR reactions were carried out as described in Gaublomme et al. (2003) and Keller and Largiadèr (2002), and PCR products were resolved on an ABI3130 automated DNA sequencer (Applied Biosystems, Gent, Belgium) using an internal size standard (GS500Liz; Applied Biosystems). Microsatellite allele sizing and binning were conducted with GENEMAPPER v3.7 (Applied Biosystems).

\section{Statistical analyses}

We first tested for deviations from Hardy-Weinbergequilibrium (HWE) and linkage disequilibrium using a Markov chain method implemented in GENEPOP 3.4 (Raymond \& Rousset, 1995; Rousset, 2008) for each locus and for each sample $(n=29)$. Deviations from 


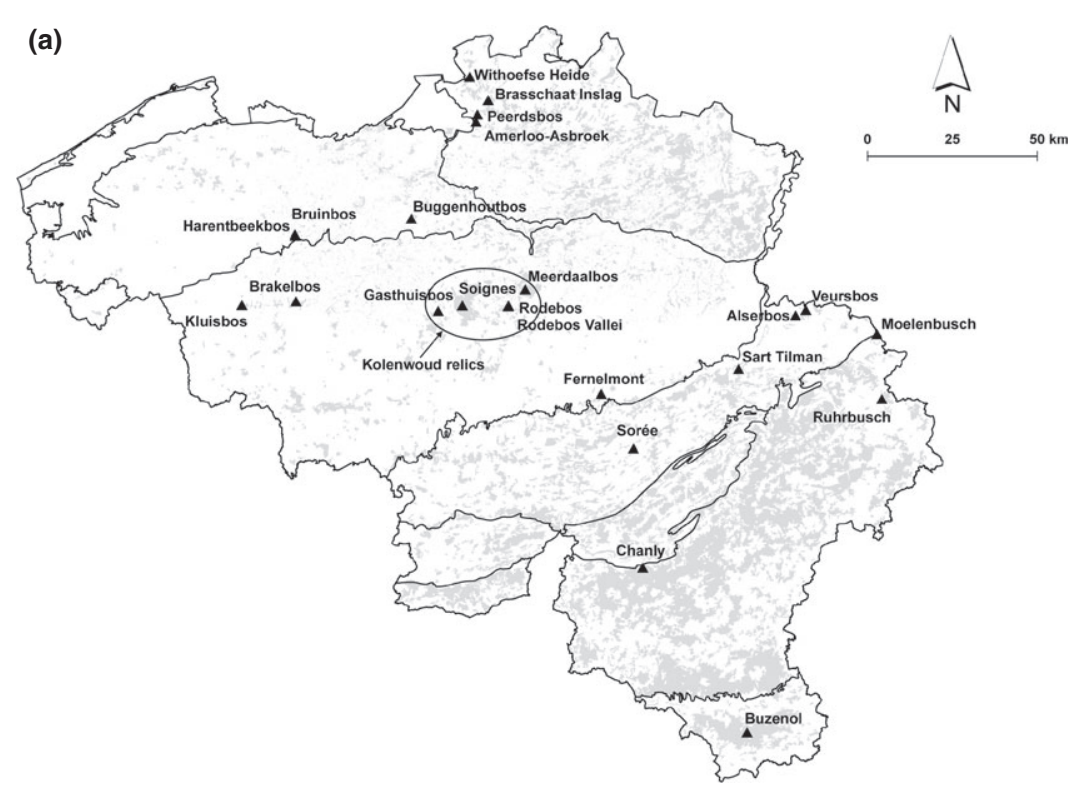

(b)

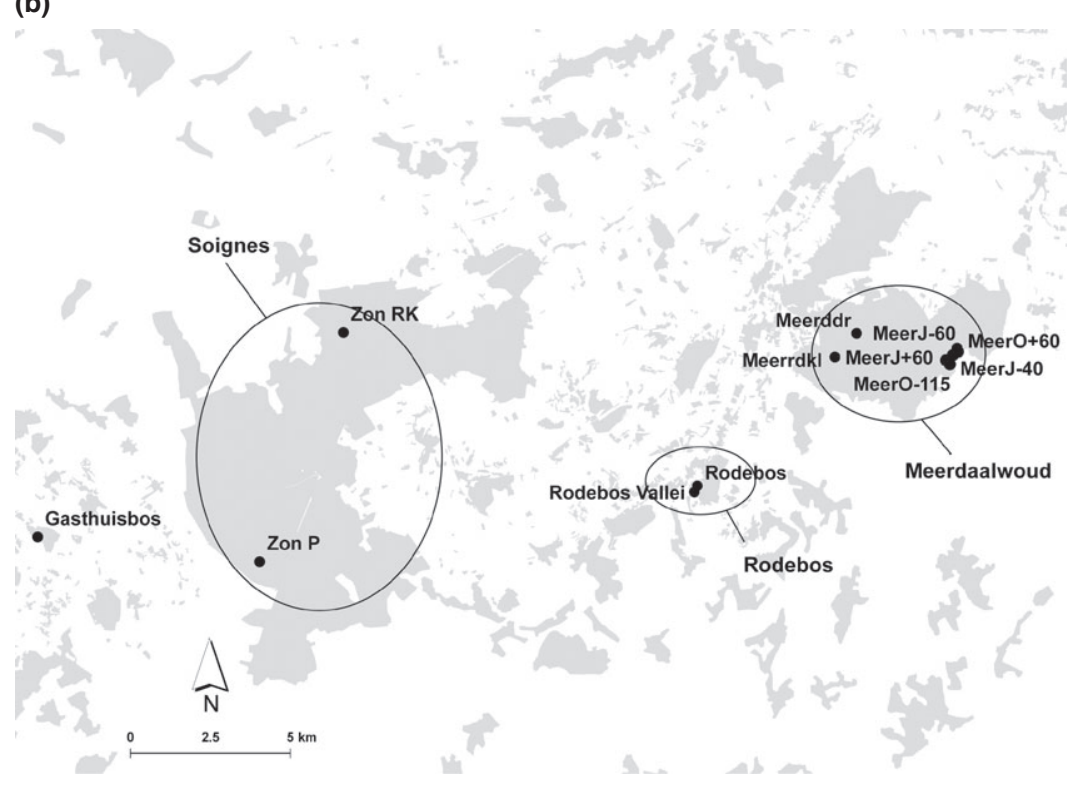

Fig. 1. Geographical distribution of studied Carabus problematicus populations in Belgium. Forests are indicated in grey and sampling locations with triangles. The black border lines represent Belgian ecoregions. (a) Detail of the four Kolenwoud fragments with 12 sampled populations of C. problematicus. (b) For position and location see Fig. 3.

Hardy-Weinberg proportions were quantified by the unbiased estimator of Wright's inbreeding coefficient $F_{\text {IS }}$ according to Weir and Cockerham (1984). Significance levels were adjusted for multiple testing using sequential Bonferroni corrections (Rice, 1989). Overall $F_{\text {ST }}$ was calculated in FSTAT ver 2.9.3 (Goudet, 2001).

For each sample $(n=29)$, genetic diversity was assessed as allelic richness (AR; El Mousadik \& Petit, 1996) as a sample size independent measure of genetic diversity in FSTAT ver 2.9.3 (Goudet, 2001) and average expected heterozygosity $\left(\mathrm{H}_{\mathrm{e}}\right)$, average observed heterozygosity $\left(\mathrm{H}_{\mathrm{o}}\right)$ and average number of alleles per locus (A) using POP100GENE 1.1.02. (http://www.montpellier.inra.fr/ URLB/pop100gene/pop100gene.html). To test whether or not genetic diversity decreased with decreasing fragment size, these four diversity indices were correlated (Spearman rank order correlation coefficient) to log transformed forest area in STATISTICA 6.0. (StatSoft Inc., Hamburg, Germany, 1998).

To identify putative recent reductions in effective population size, we used the heterozygosity excess test implemented in BOTTLENECK 1.2.02 (Piry et al., 1999) for 
(a)
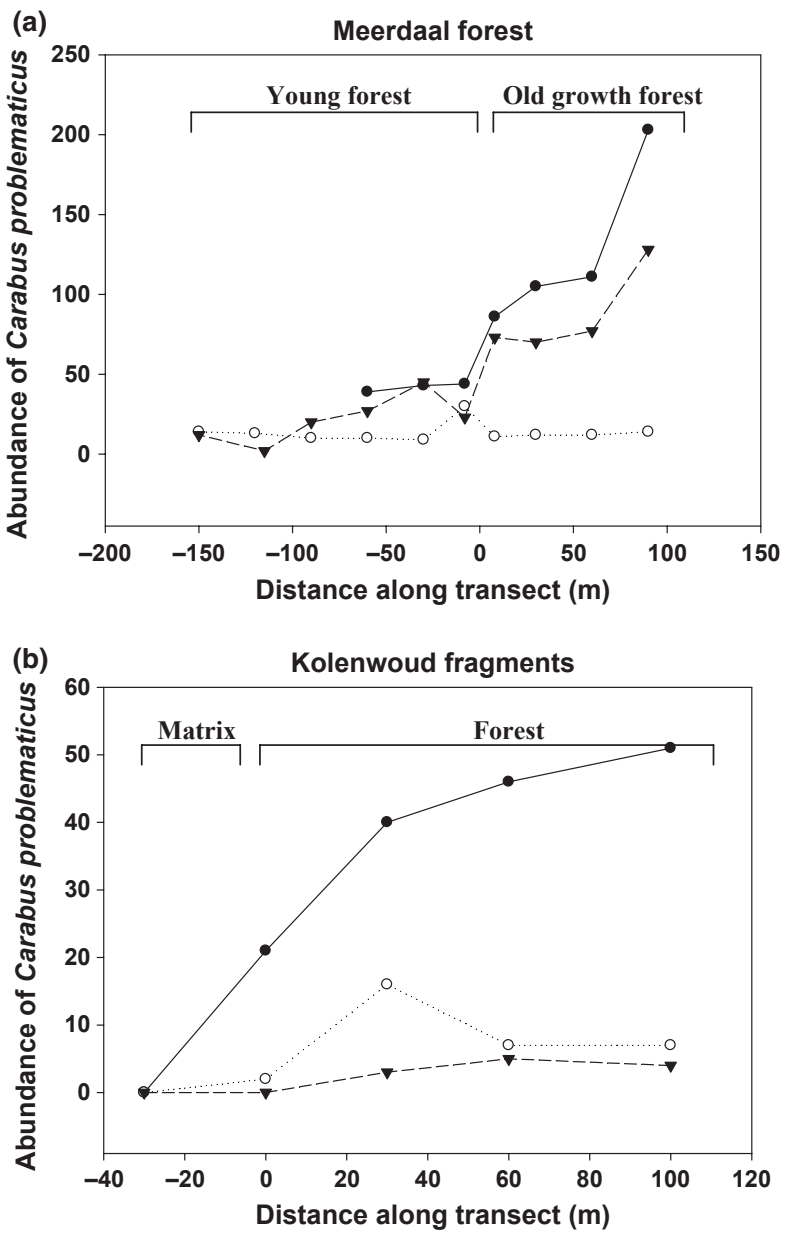

Fig. 2. Abundance of Carabus problematicus along transects (a) of young forest extending into old growth forest (b) from $30 \mathrm{~m}$ into the matrix to $100 \mathrm{~m}$ inside the forest fragment.

each sample $(n=29)$. This software simulates the coalescence process for loci at mutation-drift equilibrium, evolving under a two-phase model of mutation as recommended for microsatellites (Cornuet \& Luikart, 1996) with 1000 iterations for significance testing using Wilcoxon signed rank tests.

Geographical distances between the sampling locations were obtained using ARCVIEW version 3.1 (ESRI, Redlands, CA, USA). The forest layer was based on CORINE land cover 2006 seamless vector data version 13 (02/2010; European Environment Agency, 2010) using land cover codes 141 (green urban areas), 311 (broadleaved forest), 312 (coniferous forest) and 313 (mixed forest), the Flemish Forest Inventory (Waterinckx \& Roelandt, 2001) and own digitisation for the forest fragments Brugmanpark and Verrewinkelbos. An isolationby-distance model (Slatkin, 1993) was used to assess the correlation between genetic and geographical distances among the fragments $(n=21)$. Significance was evaluated in GENEPOP using a Mantel test (Mantel, 1976) with 10000 permutations (Raymond \& Rousset, 1995; Rousset, 2008) using $\left(F_{\mathrm{ST}} / 1-F_{\mathrm{ST}}\right)$ against the natural logarithm of geographical distance.

We subsequently focused on the spatially more restricted set of samples originating from the Kolenwoud remnants near Brussels to investigate the relative effects of genetic drift and gene flow among patches in more detail. We compared the isolation-by-distance pattern among samples within fragments with the pattern observed among samples originating from different forest fragments. For this restricted set of samples, we also quantified the partitioning of genetic variation at different hierarchical levels that is among forests $(n=4)$; among samples within forests $(n=12)$ and among individuals within populations by means of AMOVA (Excoffier et al., 1992) as implemented in ARLEQUIN 2.0 (Schneider et al., 2000).

To assess the relative importance of forest size and geographical isolation on the genetic structure, we used a hierarchical Bayesian linear model implemented in GESTE v.2.0 (Foll \& Gaggiotti, 2006). Here, sample specific $F_{\mathrm{ST}}$ 's are estimated and related to a set of explanatory variables in a linear model. The estimation of population specific

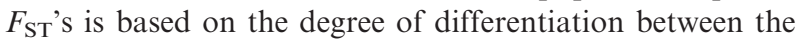
estimated allele frequencies of each subpopulation with the estimated allele frequencies of the estimated ancestral population. The program allows a set of nested models to be entered that can then be compared based on their posterior model probabilities. By mean of this model, we tested if population specific $F_{\mathrm{ST}}$ 's are related to (i) the geographical location of the sampled fragments by means of the variables latitudinal and longitudinal distance (Lambert x-coordinate) (Foll \& Gaggiotti, 2006) and (ii) area of forest fragment. We also included their two- and three-way interactions. Model selection was conducted by means of Bayes Factors. Analyses were run for 300000 generations, of which the first 50000 were treated as burn-in period and discarded for parameter estimation. To test if there is spatial autocorrelation in fragment size (i.e. if larger fragments tended to be spatially clustered), we quantified Moran's I and tested if it was significantly larger than zero.

\section{Results}

Carabus problematicus was never found outside the forest fragments along the sampled transects (Fig. 2a; Gaublomme et al., 2008). Sampling a transect of old growth forest that persisted during the past 230 years (i.e. since the first systematic maps of de Ferraris appeared in 1770-1778), the abundance of $C$. problematicus declined drastically when sampling was extended into younger forest of 50-150 years old (Fig. 2b). This demonstrates that its specific habitat requirements, that is strictly bound to forest and preferably old growth forest, combined with its inability to disperse by flight, are the more determining factors that restrict dispersal among forest fragments. 

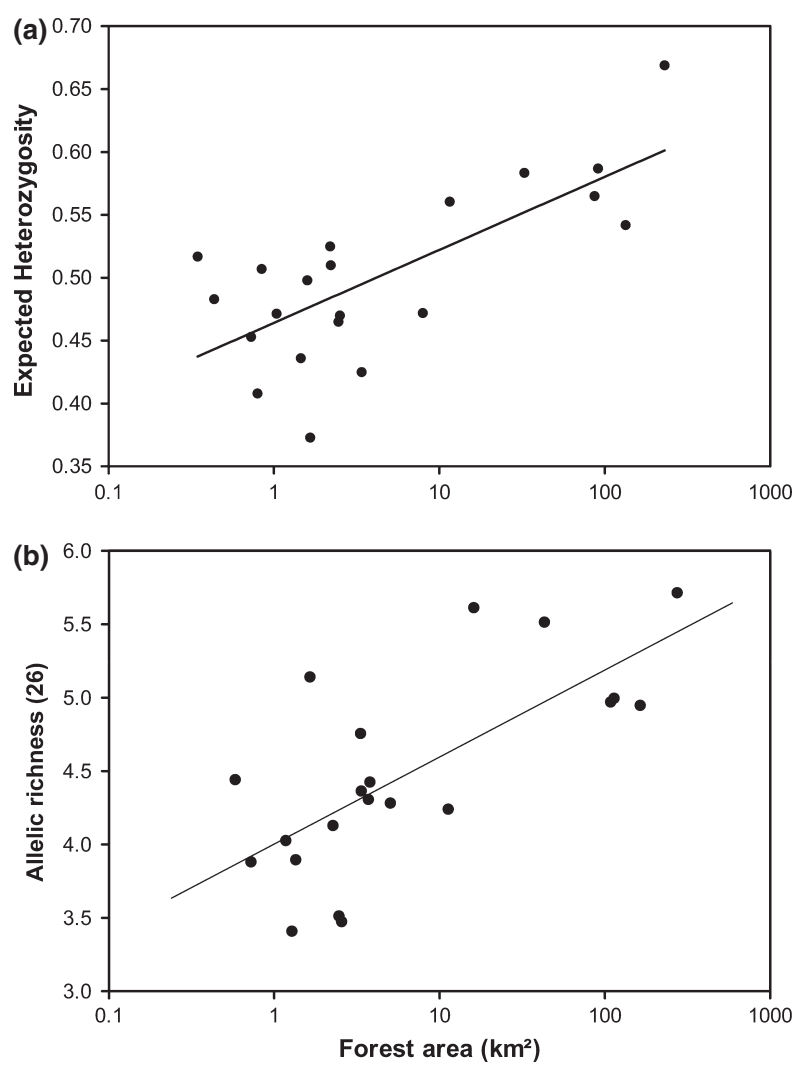

Fig. 3. Relationship between forest area and average expected heterozygosity (a) and allelic richness based on 26 individuals per population over all loci (b) in Carabus problematicus

\section{Genetic diversity}

The total number of alleles per locus ranged from 7 to 27 . Eleven alleles (of a total of 89 alleles at seven loci) were present at all sampling sites, whereas 11 alleles were private and only found in 10 different samples, originating from seven different fragments that is Moelenbusch (one allele), Meerdaalwoud (four alleles), Soignes (one allele), Chanly (two alleles), Bruinbos (one allele), Withoefse heide (one allele) and Soree (one allele). The mean number of alleles (A), expected average heterozygosity $\left(\mathrm{H}_{\mathrm{e}}\right)$, observed average heterozygosity $\left(\mathrm{H}_{\mathrm{o}}\right)$ and AR based on 26 individuals (AR) across samples averaged to $4.83 \quad( \pm 0.17 \mathrm{SE}), \quad 0.515$ $( \pm 0.01 \mathrm{SE}), 0.482( \pm 0.01 \mathrm{SE})$ and $31.92( \pm 5.44 \mathrm{SE})$ respectively (Table 1). Locus P99 showed deviations from HWE and was withdrawn from further analyses. None of the loci were in linkage disequilibrium for any of the samples.

BOTTLENECK analysis revealed no excess of heterozygosity in any of the samples, thus, there were no traces of recent genetic bottlenecks. Inbreeding coefficients were not significantly different from zero in all samples and for all loci.

Forest fragment area was significantly and positively correlated with expected heterozygosity $(n=21, r=0.574$,
$P=0.007 ; \quad$ Fig. 3a), observed heterozygosity $(n=21$, $r=0.60 ; P=0.007)$, mean number of alleles $(n=21, r=$ 0.633, $P=0.0021$; Fig. $3 b)$ and AR $(n=21, r=0.704$; $P<0.001$ ), indicating that samples from larger forest fragments were genetically more diverse.

Genetic differentiation in response to geographical distance and forest area

Overall differentiation among samples was relatively high with $F_{\mathrm{ST}}=0.12(P \leq 0.001)$. Mantel tests showed a significant correlation between genetic distances and geographical distances when considering all forest fragments $(n=21$, $r=0.440, P=0.005$; Fig. 4a). This pattern emerged primarily because of the small genetic distance between samples originating from nearby forests. When focusing only on the Kolenwoud fragments we observe little genetic differentiation between the samples within the fragments (open circles in Fig. 4b) as compared to samples from different (nearby) fragments (filled circles in Fig. 4b). This suggests that gene flow within the often fairly large fragments is significant, in contrast to gene flow between fragments that are separated by modest stretches of unsuitable habitat matrix. This was also shown by AMOvA, where the variance among the four different forest fragments of the Kolenwoud (6.51\%; $P=0.004)$ was higher compared to the variance among samples within forest fragments $(0.24 \% ; P=0.05)$. Most of the variations, however, was explained by the variance within samples $(93.39 \% ; P<0.001)$.

The linear model approach in GESTE (Foll \& Gaggiotti, 2006) did not support a model that included the geographical structuring of the fragments. Highest support was found for a simple regression model that only included the effect of fragment area(posterior probability $=0.837$ ), which had a negative effect on fragment specific $F_{\mathrm{ST}}$-values, indicating that genetic differentiation decreased with increasing forest size (Fig. 5). Hence, samples from smaller forest fragments were significantly more differentiated than those from larger forest fragments. Only a weak and not significant degree of spatial autocorrelation in fragment area was observed (Moran's $I=0.07$; $P=0.16)$.

\section{Discussion}

This population genetic study on the forest specialist and wingless beetle $C$. problematicus shows that the genetic constitution of samples originating from different forest fragments are, in general, strongly differentiated. Our linear model approach revealed that overall forest size is the main factor influencing the genetic structure of C. problematicus, wherein samples from smaller forest fragments exhibited a considerably higher genetic differentiation compared to those from larger forest fragments. This is in strong accordance with population genetic theory wherein the intensity of genetic drift in a population is inversely 

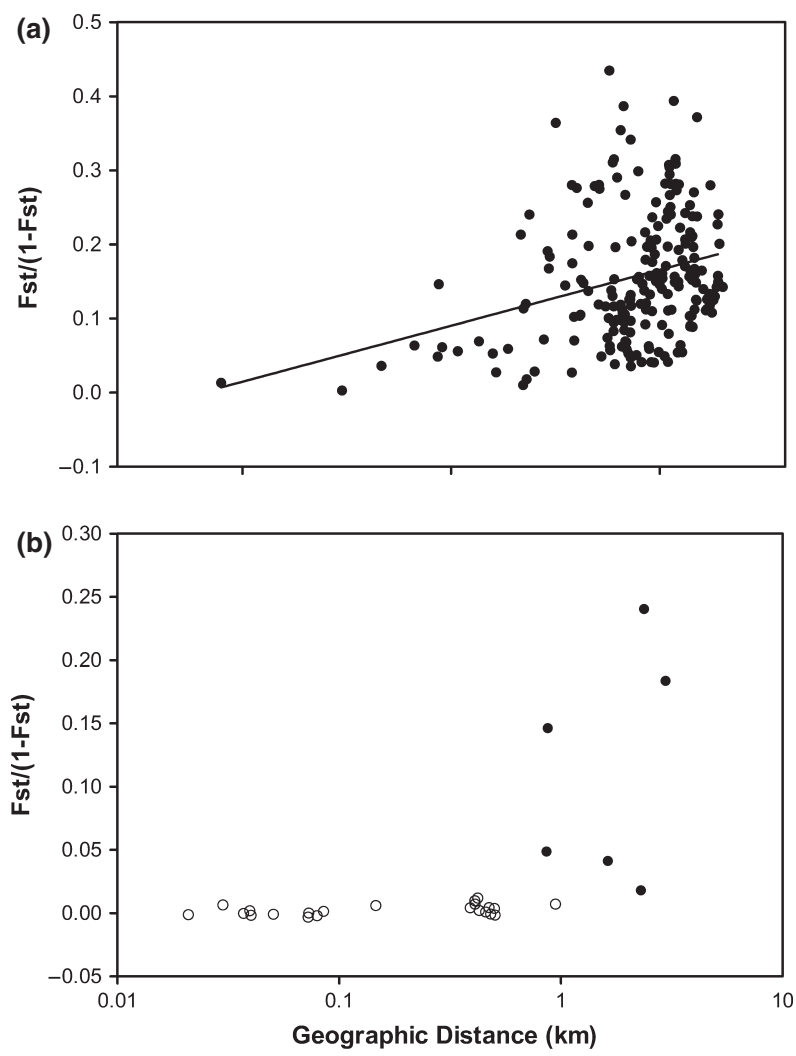

Fig. 4. Relationship between geographical $(\mathrm{km})$ and genetic $\left[F_{\mathrm{ST}} /\left(1-F_{\mathrm{ST}}\right)\right]$ distance for all sampled forest fragment populations of Carabus problematicus (a) and for Kolenwoud populations only (b). Open circles represent comparisons of populations from the same forest fragment filled circles represent population comparisons from different forest fragments.

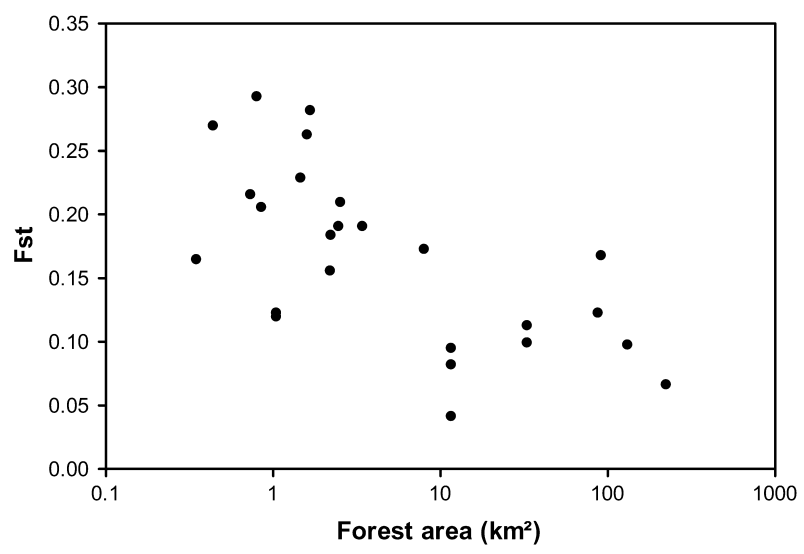

Fig. 5. Relationship between population specific $F_{\mathrm{ST}}$-values and forest area in Carabus problematicus.

related to its effective size (Taylor, 2003; Hedrick, 2005). This demonstrates that at least for our smaller fragments, drift processes are only counteracted by migration among fragments to a minor extent. In case of strong genetic drift, it is expected that particular alleles may become locally extinct, thus eroding local genetic diversity (Slatkin, 1987) and can further lead to decreased heterozygosity and inbreeding depression, which further enhances the risk of local extinction (Saccheri et al., 1998; Frankham et al., 2002). That this loss of local genetic diversity is currently ongoing in our smaller fragments was evidenced by a positive relationship between all measures of genetic diversity and forest fragment area. Although higher differentiation among populations may increase genetic variation at a regional level (Slatkin, 1987; Hanski \& Gilpin, 1991), this pattern was not observed in this study. For example, unique alleles were almost only found in the larger forest fragments. A comparable result was found for other ground beetles, albeit in other habitat types (Desender, 2005; Drees et al., 2011) and for other insects (Knutsen et al., 2000; Williams et al., 2003; Keyghobadi et al., 2005) Whether or not this loss of genetic diversity effectively decreases the adaptive potential of these smaller populations remains, however, elusive as the use of neutral genetic markers only gives an indirect estimate of the genetic variation at loci under selection.

In Belgium, C. problematicus was never recorded in forests smaller than 30 hectares. Recent studies, however, suggested that observed area effects are driven by edge effects (Ewers et al., 2007), as smaller fragments undergo proportionally stronger edge effects as compared to larger fragments (Murcia, 1995; Didham et al., 1998a,b; Ewers \& Didham, 2006; Ewers et al., 2007; Fletcher et al., 2007). This can result in a lower habitat quality of the smaller fragments and eventually to a lower genetic diversity. Disappearance of forest specialist species in fragmented patches is often explained by the replacement of habitat specialists that are bound to the interior of the patch with species residing in the matrix habitat (Halme \& Niëmela, 1993; Lövei \& Sunderland, 1996; Ås, 1999; Magura et al., 2001, 2010; Summerville \& Crist, 2004; Didham et al., 2007; Ewers et al., 2007; Hendrickx et al., 2009). Ewers et al. (2007) found evidence of a strong interaction between habitat area and edge effects, changing exponentially with increasing fragment area. A reduced population size enhances the risk of diversity loss due to drift processes (Taylor, 2003; Hedrick, 2005) and generates populations that are genetically more distinct from each other, thus with a higher differentiation rate (Williams et al., 2003; Sumner et al., 2004; Noël et al., 2007; Biedrzycka \& Konopinski, 2008).

Although drift processes play a major role in determining the genetic structure, at least in smaller populations, it is challenging to quantify and infer the amount of gene flow and migration among and within fragments. At the larger geographical scale of Belgium, the clear isolation-by-distance relationship at first suggests an equilibrium between drift and gene flow (Hutchison \& Templeton, 1999). Yet, it should be noted that a smaller genetic distance among nearby samples remains hard to distinguish from a shared evolutionary history experienced by neighbouring samples. A more detailed visual inspection on a spatially more restricted dataset of the Kolenwoud samples, sharing the 
same evolutionary history showed that differentiation among populations originating from different fragments was significant and considerably higher compared to genetic differentiation of populations originating from the same fragment, which was almost absent. This suggests that the relationship between geographical and genetic distance was primarily caused by the small genetic distance of a few neighbouring samples, pointing towards migration events being restricted to those fragments. This result was confirmed with the AMOVA analysis where a higher variance was found among the different forest fragments compared to the samples within the same forest fragment, even at relatively large geographical distances.

The restricted dispersal of $C$. problematicus, is most probably not simply due to its absence of flight capability (Neumann, 1971; Rijnsdorp, 1980), but also largely based on its stringent habitat requirements. Indeed, in a former study conducted in the same area of Brussels, strict forest specialists were never found outside forest fragments, independent of the type of matrix and these species even avoided edge habitats (Gaublomme et al., 2008). Brouat et al. (2003) showed that non-forested areas were partial barriers to gene flow for the forest specialist species C. punctatoauratus and the forest species C. nemoralis.

The results of our population genetic study are also consistent with previous community level studies where carabid assemblages of smaller fragments were found to be significantly less diverse in number of short winged species (Hendrickx et al., 2009). In accordance with these results, stochastic effects most probably play an important role for brachypterous species in smaller fragments and may ultimately drive local populations towards extinction. Based on the genetic results obtained from this study and the fact that the species has not been observed outside the forest patches (Gaublomme et al., 2008), it is unlikely that the high frequency of empty patches are caused by metapopulation dynamics occurring within this set of populations, wherein local extinctions are compensated by recurrent recolonisations (Hanski, 1998). Insights into the genetic structure of threatened populations, particularly those existing in fragmented habitats, are thus relevant for the management and conservation. Our study suggests that an unsuitable matrix poses a barrier to species with low dispersal capacity and high habitat specificity. Establishing new forests would therefore be of only limited use for specialist species, as they may not colonise new patches readily. A more suitable management option, derived from our study results, might be to preserve and enlarge existing forest fragments, while corridors connecting remaining habitat fragments would only be useful if they were substantial in area and would contain core old growth habitat.

\section{Acknowledgements}

Our special thanks goes to Konjev Desender, who unfortunately passed away during writing this manuscript. He provided us with his passion and knowledge of carabid beetles for which we are particularly grateful. We would like to thank R. Holderegger for the many useful comments on this manuscript as well as two anonymous referees who provided useful comments. We would also like to thank A. Drumont and W. Fannes for their assistance in the field and in the laboratory and V. Versteirt and T. Adriaens for their help with drawing the maps as well as graphs and comments on this manuscript. We also thank the Belgian authorities for their permissions to sample the forests. This research was funded by a $\mathrm{PhD}$ grant to EG of the Institute for the Promotion of Innovation through Science and Technology in Flanders (IWTVlaanderen) and the Belgian Science Policy (BELSPO, $\mathrm{MO} / 36 / 014)$. This work was partly conducted within the framework of the Interuniversity Attraction Poles programma IAP (SPEEDY) - Belgian Science Policy.

\section{References}

Ås, S. (1999) Invasion of matrix species in small habitat patches. Conservation Ecology, 3, 1.

Biedrzycka, A. \& Konopinski, M. (2008) Genetic variability and the effect of habitat fragmentation in spotted duslik Spermophilus suslicus populations from two different regions. Conservation Genetics, 9, 1211-1221.

Bloemers, J. \& Van Dorp, A. (1991) Pre- and protohistorie van de Lage Landen. Open Universiteit, De Haan, the Netherlands.

Bossuyt, B., Hermy, M. \& Deckers, J. (1999) Migration of herbaceous plant species across ancient-recent forest ecotones in Central Belgium. Journal of Ecology, 87, 628-638.

Brouat, C., Chevallier, H., Meusnier, S., Noblecourt, T. \& Rasplus, J.Y. (2004) Specialization and habitat: spatial and environmental effects on abundance and genetic diversity of forest generalist and specialist Carabus species. Molecular Ecology, 13, 1815-1826.

Brouat, C., Sennedot, F., Audiot, P., Leblois, R. \& Rasplus, J.Y. (2003) Fine-scale genetic structure of two carabid species with contrasted levels of habitat specialization. Molecular Ecology, 12, 1731-1745.

Cornuet, J.M. \& Luikart, G. (1996) Description and power analysis of two tests for detecting recent population bottlenecks from allele frequency data. Genetics, 144, 2001-2014.

Desender, K. (2005) Theory versus reality: a review on the ecological and population genetic effects of forest fragmentation on wild organisms, with an emphasis on ground beetles. DIAS Reports, 114, 49-72.

Desender, K., Ervynck, A. \& Tack, G. (1999) Beetle diversity and historical ecology of woodlands in Flanders. Belgian Journal of Zoology, 129, 139-156.

Didham, R., Hammond, P., Lawton, J., Eggleton, P. \& Stork, N. (1998a) Beetle species responses to tropical forest fragmentation. Ecological Monographs, 68, 295-323.

Didham, R., Lawton, J., Hammond, P. \& Eggleton, P. (1998b) Trophic structure stability and extinction dynamics of beetles (Coleoptera) in tropical forest fragments. Philosophical Transactions of the Royal Society of London B, 353, 437-451.

Didham, R., Tylianakis, J., Gemmel, N., Rand, T. \& Ewers, R. (2007) Interactive effects of habitat modification and species invasion on native species decline. Trends in ecology and evolution, 22, 489-496. 
Drees, C., De Vries, H., Härdtle, W., Matern, A., Persigehl, M. \& Assmann, T. (2011) Genetic erosion in a stenotopic heathland ground beetle (Coleoptera: Carabidae): a matter of habitat size? Conservation Genetics, 12, 105-117.

Ebert, D., Haag, C., Kirkpatrick, M., Riek, M., Hottinger, J. \& Pajunen, V. (2002) A selective advantage to immigrant genes in a Daphnia metapopulation. Science, 295, 485-488.

El Mousadik, A. \& Petit, R. (1996) High level of genetic differentiation for allelic richness among populations of the argan tree (Argania spinosa (L.) Skeels) endemic to Morocco. Theoretical and Applied Genetics, 92, 832-839.

Ervynck, A., Desender, K., Pieters, M. \& Bungeneers, J. (1994) Carabid beetles as paleo-ecological indicators in archaeology. Carabid Beetles: Ecology and Evolution (ed. by K. Desender, M. Dufrêne, M. Loreau M.L. Luff and J.-P. Maelfait), pp. 261-266. Kluwer Academic Publishers, Dordrecht, the Netherlands.

European Environment Agency (2010) Corine Land Cover 2006 (CLC 2006) Seamless Vector Data - Version 13 (02/2010). European Topic Centre on Land Use and Spatial Information. $<$ http://www.eea.europa.eu/data-and-maps/data/clc-2006-vectordata-version $>$ 14th June 2011.

Ewers, R. \& Didham, R. (2006) Confounding factors in the detection of species responses to habitat fragmentation. Biological Reviews, 81, 117-142.

Ewers, R., Thorpe, S. \& Didham, R. (2007) Synergistic interactions between edge and area effects in a heavily fragmented landscape. Ecology, 88, 96-106.

Excoffier, L., Smouse, P. \& Quattro, J. (1992) Analysis of molecular variance inferred from metric distances among DNA haplotypes: application to human mitochondrial DNA restriction data. Genetics, 131, 479-491.

Fletcher, R., Ries, L., Battin, J. \& Chalfoun, A. (2007) The role of habitat area and edge in fragmented landscapes: definitely distinct or inevitably intertwined? Canadian Journal of Zoology, 85, 1017-1030.

Foll, M. \& Gaggiotti, O. (2006) Identifying the environmental factors that determine the genetic structure of populations. Genetics, 174, 875-891.

Frankham, R. (1995) Inbreeding and extinction: a threshold effect. Conservation Biology, 9, 792-799.

Frankham, R. (1996) Relationship of genetic variation to population size in wildlife. Conservation Biology, 10, 1500-1508.

Frankham, R., Ballou, J. \& Briscoe, D. (2002) Introduction to Conservation Genetics. Cambridge University Press, Cambridge, UK.

Gaublomme, E., Dhuyvetter, H., Verdyck, P., Dhuyvetter, H. \& Rasplus, J.Y. (2003) Isolation and characterization of microsatellite loci in the ground beetle Carabus problematicus (Coleoptera, Carabidae). Molecular Ecology Notes, 3, 341-343.

Gaublomme, E., Hendrickx, F., Dhuyvetter, H. \& Desender, K. (2008) The effects of forest patch size and matrix type on changes in carabid beetle assemblages in an urbanised landscape. Biological Conservation, 141, 2585-2596.

Goudet, J. (2001) FSTAT, a Program to Estimate and Test Gene Diversities and Fixation Indices (Version 2.9.3). < http://www. unil/ch/izea/softwares/fstat.html > 4th February 2012.

Halme, E. \& Niëmela, J. (1993) Carabid beetles in fragments of coniferous forest. Annales Zoologici Fennici, 30, 17-30.

Hanski, I. (1998) Metapopulation dynamics. Nature, 396, 41-49.

Hanski, I. \& Gilpin, M. (1991) Metapopulation dynamics - brief -history and conceptual domain. Biological Journal of the Linnean Society, 42, 3-16.
Harris, L. (1984) The Fragmented Forest: Island Biogeography Theory and the Preservation of Biotic Diversity. University of Chicago Press, Chicago, Illinois.

Hedrick, P. (2005) Genetics of Populations. Jones and Bartlett, London, UK.

Heisswolf, A., Reichmann, S., Poethke, H., Schröder, B. \& Obermaier, E. (2009) Habitat quality matters for the distribution of an endangered leaf beetle and its egg parasitoid in a fragmented landscape. Journal of Insect Conservation, 13, $165-175$.

Hendrickx, F., Maelfait, J.P., Desender, K., Aviron, S., Bailey, D., Diekötter, T., Lens, L., Liira, J., Schweiger, O., Speelmans, M., Vandomme, V. \& Bugter, R. (2009) Pervasive effects of dispersal limitation on within- and among-community species richness in agricultural landscapes. Global Ecology and Biogeography, 18, 607-616.

Hermy, M., Honnay, O., Firbank, L., Grashof-Bokdam, C. \& Lawesson, J. (1999) An ecological comparison between ancient and other forest plant species of Europe, and the implications for forest conservation. Biological Conservation, 91, 9-22.

Honnay, O., Hermy, M. \& Coppin, P. (1999) Effects of area, age and diversity of forest patches in Belgium on plant species richness, and implications for conservation and reforestation. Biological Conservation, 87, 73-84.

Honnay, O., Jacquemyn, H., Bossuyt, B. \& Hermy, M. (2005) Forest fragmentation effects on patch occupancy and population viability of herbaceous plant species. New Phytologist, 166, 723-736.

Hutchison, D. \& Templeton, A. (1999) Correlation of pairwise genetic and geographic distance measures: inferring the relative influences of gene flow and drift on the distribution of genetic variability. Evolution, 53, 1898-1914.

Keller, I., Excoffier, L. \& Largiader, C. (2005) Estimation of effective population size and detection of a recent population decline coinciding with habitat fragmentation in a ground beetle. Journal of Evolutionay Biology, 18, 90-100.

Keller, I. \& Largiadèr, C. (2002) Identification of one X-linked and five autosomal microsatellite loci in Carabus violaceus (Coleoptera, Carabidae) and their applicability to related taxa. Molecular Ecology Notes, 2, 290-292.

Keyghobadi, N. (2007) The genetic implications of habitat fragmentation for animals. Canadian Journal of Zoology, 85, 10491064.

Keyghobadi, N., Roland, J. \& Strobeck, C. (2005) Genetic differentiation and gene flow among populations of the alpine butterfly, Parnassius smintheus, vary with landscape connectivity. Molecular Ecology, 14, 1897-1909.

Knutsen, H., Rukke, B., Jorde, P. \& Ims, R. (2000) Genetic differentiation among populations of the beetle Bolitophagus reticulatus (Coleoptera: Tenebrionidae) in a fragmented and a continuous landscape. Heredity, 84, 667-676.

Lefèbvre, S. (1997) Les pépinières dans les Pays-Bas autrichiens: le cas de Soignes. Etudes sur le XVIIIe siècle XXV-Parcs, jardins et forêts au XVIIIe siècle (ed. by R. Mortier and H. Hasquin), pp. 39-77. Université Libre de Bruxelles, Bruxelles, Belgium.

Leisnham, P. \& Jamieson, I. (2002) Metapopulation dynamics of a flightless alpine insect Hemideina maori in a naturally fragmented habitat. Ecological Entomology, 27, 574-580.

Lövei, G. \& Sunderland, K. (1996) Ecology and behavior of ground beetles (Coleoptera: Carabidae). Annual Review of Entomology, 41, 231-256. 
Magura, T., Lövei, G. \& Tóthmérész, B. (2010) Does urbanizaton decrease diversity in ground beetle (Carabidae) assemblages? Global Ecology and Biogeography, 19, 16-26.

Magura, T., Tothmeresz, B. \& Molnar, T. (2001) Forest edge and diversity: carabids along forest-grassland transects. Biodiversity and Conservation, 10, 287-300.

Mantel, N. (1976) The detection of disease clustering and a generalised regression approach. Cancer Research, 27, 209-220.

Meffe, G. \& Caroll, C. (1997) Principles of Conservation Biology. Sinauer, Sunderland, Massachusetts.

Murcia, C. (1995) Edge effects in fragmented forests: implications for conservation. Trends in Ecology and Evolution, 10, $58-62$.

Neumann, U. (1971) Die Ausbreitungsfähigkeit von Carabiden in den forschtlichen Rekultivierungen des Rheininschen Braunkohlenreviers. Dispersal and Dispersal Power of Carabid Beetles (ed. by P.J. Den Boer), pp. 89-100. Venmann en Zonen, Wageningen, the Netherlands.

Noël, S., Ouellet, M., Galois, P. \& Lapointe, F. (2007) Impact of urban fragmentation on the genetic structure of the eastern red-backed salamander. Conservation Genetics, 8, 599-606.

Piry, S., Luikart, G. \& Cornuet, J.M. (1999) BOTTLENECK: a computer program for detecting recent reductions in the effective population size using allele frequency data. Journal of Heredity, 90, 202-203.

Raymond, M. \& Rousset, F. (1995) GENEPOP (version 1.2): population genetics software for exact tests and ecumenicism. Journal of Heredity, 86, 248-249.

Reed, D. \& Frankham, R. (2003) Correlation between fitness and genetic diversity. Conservation Biology, 17, 230-237.

Rice, W. (1989) Analyzing tables of statistical tests. Evolution, 43, 223-225.

Rijnsdorp, A. (1980) Pattern of movement in and dispersal from a Dutch forest of Carabus problematicus Herbst (Coleoptera, Carabidae). Oecologia, 45, 274-281.

Roland, J., Keyghobadi, N. \& Fownes, S. (2000) Alpine Parnassus butterfly dispersal: effects of landscape and population size. Ecology, 81, 1642-1653.

Rousset, F. (2008) GENEPOP'007: a complete reimplementation of the GENEPOP software for Windows and Linux. Molecular Ecology Research, 8, 103-106.

Saccheri, I., Brakefield, P. \& Nichols, R. (1996) Severe inbreeding depression and rapid fitness rebound in the butterfly Bicyclus anynana (Satyridae). Evolution, 50, 2000-2013.

Saccheri, I., Kuussaari, M., Kankare, M., Vikman, P., Fortelius, W. \& Hanski, I. (1998) Inbreeding and extinction in a butterfly metapopulation. Nature, 392, 491-494.

Schneider, S., Roessli, D. \& Excoffier, L. (2000) ARLEQUIN 2.000. A Software for Population Genetics Data Analysis. Genetics and Biometry Laboratory, University of Geneva, Geneva, Switzerland.

Slatkin, M. (1987) Gene flow and the geographic structure of natural populations. Science, 236, 787-792.

Slatkin, M. (1993) Isolation by distance in equilibrium and nonequilibrium populations. Evolution, 47, 264-279.
StatSoft Inc. (1998) STATISTICA version 6.0. StatSoft Inc (Europe), Hamburg, Germany.

Streiff, R., Veyrier, R., Audiot, P., Meusnier, S. \& Brouat, C. (2005) Introgression in natural populations of bioindicators: a case study of Carabus splendens and Carabus punctatuauratus. Molecular Ecology, 14, 3775-3786.

Summerville, K. \& Crist, T. (2004) Contrasting effect of habitat quantity and quality on moth communities in fragmented landscapes. Ecography, 27, 3-12.

Sumner, J., Jessop, T., Paetkau, D. \& Moritz, C. (2004) Limited effect of anthropogenic habitat fragmentation on molecular diversity in a rain forest skink, Gnypetoscincus queenslandiae. Molecular Ecology, 13, 259-269.

Tack, G. \& Hermy, M. (1998) Historical ecology of woodlands in Flanders. The Ecological History of European Forests (ed. by K. Kirkby and C. Waitkins), pp. 283-292. CABI, Wallingford, UK.

Tack, G., Van den Bremt, P. \& Hermy, M. (1993) Bossen van Vlaanderen: Een historische Ecologie. Davidsfonds, Leuven, Belgium.

Taylor, A. (2003) Assessing the consequences of inbreeding for population fitness: past challenges and future prospects. Reproductive Science and Integrated Conservation (ed. by W. Holt, A. Pickard, J. Rodger, and D.Wildt) pp. 67-81. CUP, Cambridge, UK.

Turin, H. (2000) De Nederlandse Loopkevers, Verspreiding en Oecologie (Coleoptera; Carabidae). Nationaal Natuurhistorisch Museum Naturalis, Leiden, the Netherlands.

Van de Velde, J. (1992) Zoniënbos - Ontwerpbeheersplan. Houtvesterij Groenendaal, Hoeilaart, Belgium.

Van der Ben, D. (1992) Het Zoniënwoud. Een natuurmonument en zijn geschiedenis. Lannoo, Tielt, Belgium.

Verhulst, A. (1995) Landschap en landbouw in middeleeuws Vlaanderen. Gemeentekrediet, Gent, Belgium.

Waterinckx, M. \& Roelandt, B. (2001) De bosinventarisatie van het Vlaamse Gewest. Deel 1: Methodiek. Ministerie van de Vlaamse Gemeenschap, Afdeling Bos en Groen, Brussels, Belgium.

Weir, B. \& Cockerham, C. (1984) Estimating F-statistics for the analysis of population structure. Evolution, 38, 1358-1370.

Westemeier, R., Brawn, J., Simpson, S., Esker, T., Jansen, R. \& Walk, J. (1998) Tracking the long-term decline and recovery of an isolated population. Science, 282, 1695-1698.

Wiens, J., Schooley, R. \& Weeks, R. (1997) Patchy landscapes and animal movements: do beetles percolate? Oikos, 78, 257-264.

Williams, B., Brawn, J. \& Paige, K. (2003) Landscape scale genetic effects of habitat fragmentation on a high gene flow species: Speyeria idalia (Nymphalidae). Molecular Ecology, 12, $11-20$.

Accepted 11 September 2012

First published online 6 November 2012

Editor/associate editor: Jacobus Boomsma 